Saudi Journal of Business and Management Studies Abbreviated Key Title: Saudi I Bus Manag Stud ISSN 2415-6663 (Print) |ISSN 2415-6671 (Online) Scholars Middle East Publishers, Dubai, United Arab Emirates Journal homepage: https://saudijournals.com/sjbms

Original Research Article

\title{
Assessment of Casual Labor Management Practices in Construction Projects
}

\author{
Er. Roshan Dev ${ }^{1}$, Dr. Anjay Kumar Mishra ${ }^{2 *}$ \\ ${ }^{1}$ Resident Engineer, Umar Munshi Associates Association with ERMC-PACE-PRCS \\ ${ }^{2}$ Associate Professor and Research Director, Madan Bhandari Memorial Academy Nepal and Pokhara University, Urlabari 3, Morang, Nepal
}

DOI: $10.36348 /$ sjbms.2020.v05i09.001

| Received: 21.08.2020 | Accepted: 29.08.2020 | Published: 09.09.2020

*Corresponding author: Anjay Kumar Mishra

\section{Abstract}

Construction in developing countries is still influenced by the labour force. Overall objective of the study is to analyse the challenges for improvisation on labour management system through work efficiency. Department of Hydrology and Meteorology (DHM) office, Department of Food Technology and Quality Control (DFTQC) office building and Dhobi Khola Bridge along Arniko highway- at bijulibazar were selected for the study. Schedule questionnaire survey with labours, interview with agents or labour supplier clients, contractor and their project manager were conducted at each selected site for primary data collection. Attendance records, minute of meetings of all three site as well different journal were analysed and reviewed for collecting secondary data. Fluctuation in availability of labor were found mainly in months of January, June, September, October due to festivals and agricultural purposes as very few of labors were specific labor for the industry. Pilling works were mostly done by the labor from India. Labors form Bardia, Kailali, Kanchanpur, Dhading were expertise for concrete work. Similarly labors from Dolkha, Sindupalchowk, Saptari, Dhading were engaged in from work. Rebar works were found to be performed by the labors from Saptari, Siraha, Udayapur, Sunsari where as labors from Dhading, Sindhupalchowk, India were engaged for brick work. Labors were lacking for piling work, retrofitting and electromechanical works. Labors were not being provided any training nor has any performance test been performed, only $6 \%$ of labor were trained rest acquired skill through working experience which is the challenge for immersing work. Construction companies had maintained their labors supply through agents or labors suppliers. In spite of their agreement regarding health and safety facilities, contractors do not provide it to labors satisfactorily. Labors management lacks a definite framework for their development and performance. Labor management should be ensured by ensuring job guarantee, remuneration, health facility, provision of leave and compensation. Construction industries should ensure better labor management by facilitating working condition through clear working methodology and labor card. Regular training, tool box talk should be conducted for skill development. Rather than project award to the lowest bidder priority should be given to specification and working methodology. Health and safety facilities, site infra structure should be incorporated as the submittal of the contract document.

Keywords: Pilling, rebar, retrofitting, electromechanical, safety, site management.

Copyright @ 2020: This is an open-access article distributed under the terms of the Creative Commons Attribution license which permits unrestricted use, distribution, and reproduction in any medium for non-commercial use (NonCommercial, or CC-BY-NC) provided the original author and source are credited.

\section{INTRODUCTION}

Labor can be defined as the aggregate of all human physical and mental effort used in creation of goods and services. Labor is a primary factor of production. The size of a nation's labor force is determined by the size of its adult population, and the extent to which the adults are either working or are prepared to offer their labor for wages. "Casual workers" means to individuals who are engaged on a temporary basis to work for a period of time and whose remunerations are calculated and paid on a daily basis. Most of the projects in Nepal are operated by causal worker only [1]. Permanent staffs are getting more benefits like medical insurance, life insurance, Employee Assistance Program, Pension Plan, Tuition Assistance, Salary Premium in lieu of benefits which is not for casual worker [2]. Now labour permit system 
has been adopted for India also. Good project management in construction must vigorously pursue the efficient utilization of labor, material and equipment for value based construction [3]. Improvement of labor productivity should be a major and continual concern of those who are responsible for cost control of constructed facilities. As in most developing countries, a great portion of the construction labor also comes from farming and they work both seasonal and contingent on the need for specific skills in a project.

Due to this high cost of labor, labor cost control is a very important function for profitability in the industry. The labor cost component of electrical and mechanical works also represents $40-60 \%$ of their final cost. Therefore, labor-intensive industries such as construction are considered under high-risk by contractors due to the relatively high labor component, and, thus, any reduction in this wastage presents enormous potential for the increased efficiency [4].

In construction industry major challenges are performance, profitability and sustainability. If these challenges would be analyzed, one factor of performance and profitability would be human resource .Even though less attention towards human resource management is given. According to Jarkas and Bitar [5] in most countries, labor cost comprises 30 to $50 \%$ of the overall project's cost, and thus is regarded as a true reflection of the economic success of the operation. The quantity of labor hours in performing a task in construction is more susceptible to the influence of management compared to materials or capital. Although labor management is very important for the smooth operation of any construction project, little attention is given in Nepalese construction industry. It is significant to identify problems and their mitigation for ensuring the labor management in Nepal.

\section{RESEARCH OBJECTIVES}

The overall objective of the study is to assess the challenges and improvisation on causal labor management system and its impact on work efficiency.

\section{Study Area}

This study was carried out with different construction companies and in different construction area and they are ; Building construction for Department of Hydrology and Meteorology(DHM) office contractor Dafe Samananter JV with on an average 65 number of workers, Building construction for Department of Food Technology and Quality Control (DFTQC) office contractor Contech Pvt Ltd with 45 numbers of workers and Bridge construction at Dhobi Khola Bridge contractor Jayee Pvt Ltd have 30 number of workers working averagely.

\section{Sample selection and sample Size}

The convenient sampling is done as per Krejice and Morgan [6]. Table for each project by which sample size of the each project is determined. This study includes following sample size shown in table 1:

Table-1: Distribution of respondents according to the position

\begin{tabular}{|c|c|c|c|c|}
\hline S. No. & Project Name & Respondents & Population Size (N) & Sample Size \\
\hline \multirow[t]{4}{*}{1} & \multirow[t]{4}{*}{ Building construction for DHM office } & Labors & 65 & 56 \\
\hline & & Agents & 4 & 4 \\
\hline & & Contractors & 2 & 2 \\
\hline & & Clients & 3 & 3 \\
\hline \multirow[t]{4}{*}{2} & \multirow[t]{4}{*}{ Building construction for food technology office } & Labors & 45 & 40 \\
\hline & & Agents & 3 & 3 \\
\hline & & Contractors & 2 & 2 \\
\hline & & Clients & 3 & 3 \\
\hline \multirow[t]{4}{*}{3} & \multirow[t]{4}{*}{ Bridge construction at Dhobi Khola Bridge } & Labors & 30 & 28 \\
\hline & & Agents & 3 & 3 \\
\hline & & Contractors & 2 & 2 \\
\hline & & Clients & 3 & 3 \\
\hline
\end{tabular}

\section{Primary Data}

- Schedule Questionnaire

A set of schedule questionnaire with labor was conducted at all three working site based on their working experience, their awareness about health and safety facilities. The questions were prepared focused to assess their health and facilities and way of management along with social security.

- Interview
Interview through open ended questions were conducted with all the agent of the respective sites for gathering the information related to labor supply and demand, their mode of working, about their registration through checklist.

- Key Informants Interview

Best on snow ball sampling key informants interview was conducted to the personals of Department of Road (DoR) and the personals 
from Department of Urban Development and Building Construction (DUDBC).

\section{Secondary Data}

- Attendance records from each site were observed to find the records of labors.

- Minutes of meeting were studied to collect the information about the decision made for the facilities provided at site.

- Different journal, reports, article were analyzed and reviewed to gather information for secondary data.

\section{DATA ANALYSIS}

Descriptive analysis was done for qualitative data whereas mean score analysis was conducted. Descriptive table, comparative table, ranking table and graphs such as pie-chart, bar- diagram along with logical reasoning were used for presenting the data.

\section{Relative Importance Index (RII)}

The Relative Importance Index (RII) of determination of significance of factors was adopted because, Adnan et al. [7] asserted that to analyze data on ordinal scale (e.g. Likert scale 1-5), the application of Relative Importance Index is also suitable. The Relative Importance Index is computed as in [7]:

Where:

$$
\text { Relative Importance Index }=\frac{\sum w}{A N}=\frac{5 n 5+4 n 4+3 n 3+2 n 2+n 1}{5(n+n 2+n 3+n 4+n 5)} * 100
$$

$\mathrm{n} 1$ - number of respondents who answered "not important";

$\mathrm{n} 2$ - number of respondents who answered "not important";

n3- number of respondents who answered "neutral ";

n4 - number of respondents who answered "important";

n5 - number of respondents who answered "very important"

It is worthwhile to note that the nearer the value of importance index of the identified factor is unity (1) or $100 \%$, the more significant it is and hence, a greater impact on the rest of the variables.

\section{RESULTS AND DISCUSSION \\ Status of Labor Availability}

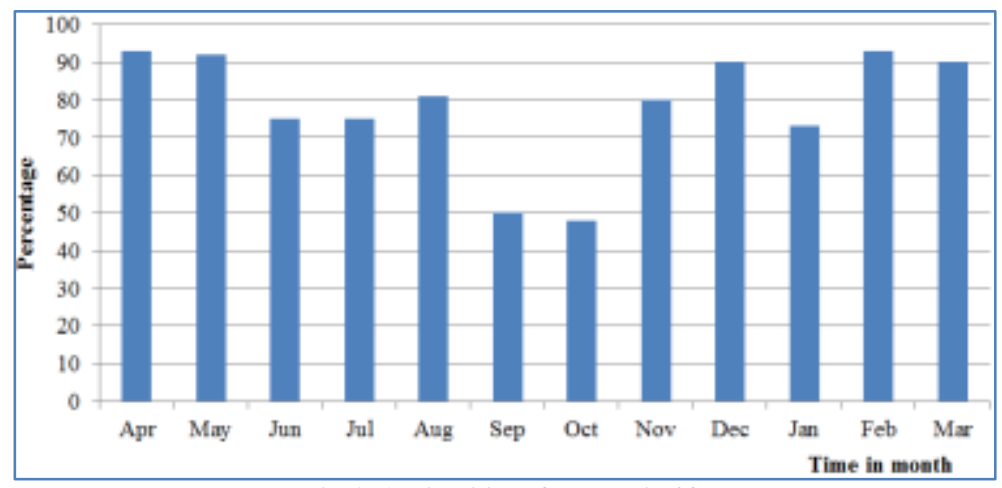

Fig-1: Availability of Labor (in \%)

Figure 1 shows the trend of availability of labor (in percentage) with respect to time as per responded by agents. Where certain fall in labor availability can be observed in months June/July, it is because of the leave taken by the labors for the agricultural purpose. Certain increment in the availability of labors can be observed during month of August, it is because of the pressure on contractors and agents to complete the work and to meet their cashflow schedule and even contractors and agents overpay the labors to complete the task. However reduction in availability of labors can be seen during the months September/October because of the festival season. Similarly, certain fall can be seen in the month of January since major number of labors belong to Bardiya, Kailali, Kanchanpur, Sirha, Saptari zone where "maghi" festival has great value due to which they desire to take leave during that month.

Table-3: Availability of labor as their permanent residence

\begin{tabular}{|l|l|l|l|l|}
\hline Concrete & Form work & Piling & Rebar & Brick work \\
\hline Bardiya & Dolakha & India & Saptari & Dhading \\
\hline Kailali & Sindhupalchowk & & Siraha & Sindhupalchowk \\
\hline Kanchanpur & Saptari & & Udaypur & India \\
\hline Dhading & Dhading & & Sunsari & \\
\hline
\end{tabular}


Table 3 shows the availability of labor as their permanent residence obtained from the agent's register. Not all the labor force belongs to same geographical zone nor performs the work of similar nature. Some of the labors are perfect in doing specific type of work only. Thus the contractors and agents require hiring labors from different region of the country and India as well. Above table indicates that for concreting works majority of the labors come from Bardiya, Kailali, Kanchanpur and Dhading. Similarly, for formwork the majority of the labors come from Dolakha, Sindhupalchowk, Saptari and Dhading. Likewise, workers for rebar come from Saptari, Sirha, Udaypur and Sunsari. Majority of the labors for brick work belong to Dhading, Sindhupalchowk and India. As equipments for piling works are not much available in Nepal and such work requires more effort and time, there is unavailability of labors for piling works as a result such labors are hired from India directly. All these sources of labors are due to trend carried out by their predecessors to perform similar work type. During key informants interview it was found that Indians are dominated for pile work not only for this project but throughout the country.

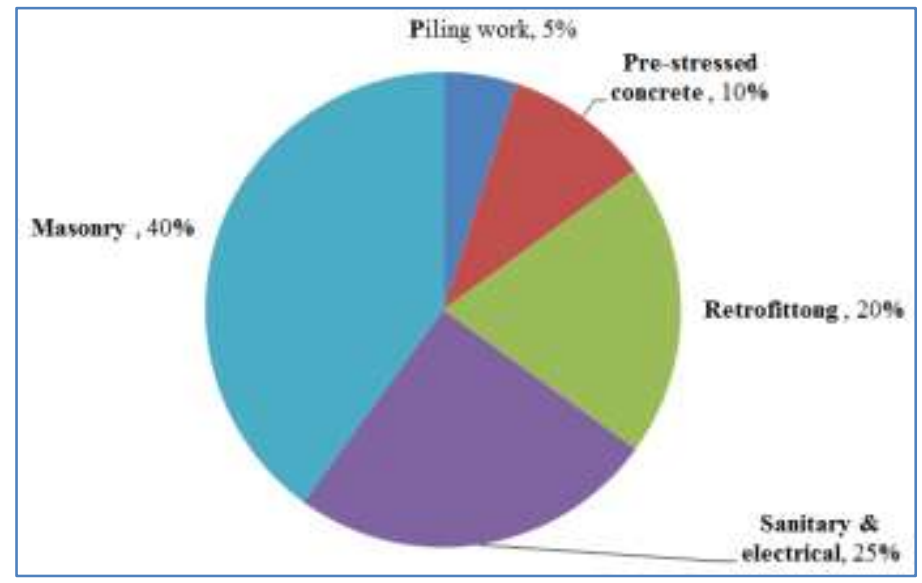

Fig-2: Availability of labor as per nature of work

Figure 2 shows the availability of labor as for nature of work as per responses provided by contractors and their engineers in the study area. The pie-chart shows that the major availability of the labor can be found for masonry work i.e. 40 percentage followed by sanitary \& electrical works (25 percentage), retrofitting works (20 percentage), pre-stressed concrete work ( 10 percentage) and least available work force are for piling i.e. 5 percentage. It is because masonry works are most common type, sanitary and electrical are in moderate condition, retrofitting works were highlighted after the earthquake so the labors are not much available for it, for pre-stressed concrete works and piling works labors are not much available in Nepal due to more time consuming and hard work and new form of work type for Nepal, thus majority of the labors are hired from India.

Depending on working methodology, working condition, type of work hazard should be identified and along with its mitigation approaches wages should be determined.

\section{Labor Management Practice}

Labor management refers to the rules and policies which govern and organize employment, how these are established and implemented and how they affect the needs and interests of employees and employers.

\section{Interview with clients about the issues related to labors}

The respondents from all three projects responded that labor management is one of the major and challenging issues in the construction industries. During preparation of BOQ issues like provision of insurance, health and safety facilities, camp facilities and toilet, traffic management are generally included. But the bidders bid low price in such items so implementation is not at satisfactory level. Clients mention that they generally address all such issues from labor which are presented in written form, but usually they do not experience such issues. They also agree that the existing labor ACT is sufficient to address the labor issues. But the ACT doesn't seem to be complied properly in construction sites.

\section{Interview with contractors about the issues related to labors}

In construction industry labor management plays a vital role for the successful completion of the project. According to them the availability of labor in the construction industries is very low, most of the work force are migrating to foreign countries due to various reasons. Due to this the availability of skilled labor forces in Nepal ranges from 10-15 \% only. They provide insurance facility as per the bill of quantity (BOQ), respondent also mentions that they provide basic requirements to the labors like drinking water, accommodation and incentives according to their performance. 


\section{Status of Labor}

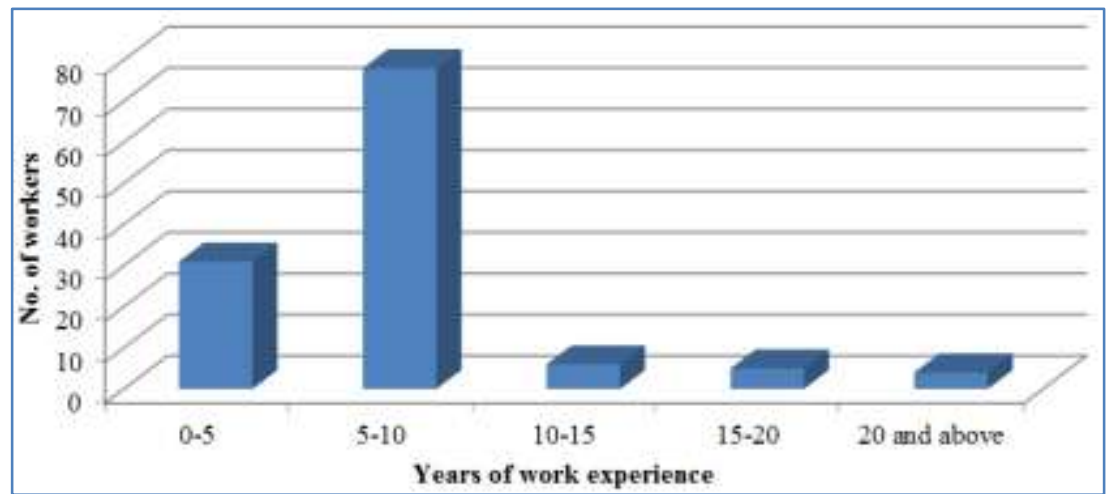

Fig-3: Status of work experience of labors

Figure 3 shows the status of work experience of labors. From the above bar diagram it can be observed that majority of the labors have working experience of 5-10 years since most of the labors are of active age group i.e. 25-35 years which are in high demand by construction industry and they themselves require the job to fulfill their financial and social needs as well. In Nepal labor laws do not allow anyone under18 years to work as labor and trend shows that after certain experience most of the labors desire to work abroad or they themselves change their mode of work such as becoming a sub- contractor. This activity indicates majority of the labors do not work as a labor for more that 5-10 years which is shown by the data too. Regarding the declination of the number of experienced workers, the causes are that either the efficiency of these workers are reduced due to old age and parallel to it their financial requirement are reduced due to enrollment and replacement of new generation.

\section{Selection of Labor}

Through the interview with contractors and project managers of contractors, it was revealed that labors are not easily available because of low job security, attraction of foreign employment opportunities, etc. Thus, the contractors execute labors through petty contract (agent).

Further interviewing with the agents / labor suppliers, it came across that these agents also face difficulty in maintaining the labor force with them due to fluctuation in rate, unavailability of labor and lack of skilled labor, so they do not hold the labor force permanently with them instead they opt for supplying the labors as per the demand of contractors. It also came across that majority of the agents were non-registered, which has been presented in following figure.

Whatever genuine data related to labor obtained from agents are based upon the registered 20 percentage which represents only $1 / 5$ of the total agents where as $80 \%$ are not registered yet. This indicates that the real labor data base is still lacking from our approach, hence we are unable to know the actual problem related to it or provide any accurate solution.

\section{Development of Labor}

The training status of labors responded by labors themselves, where only 6 percent of the labors were trained and remaining (94 percent) of them received on the job training. This on the job training only includes the basic knowledge about the specific work they are performing which is not any tested skill or separate training instead just a self gained knowledge which does not make any labor versatile in their field. It is because there is no sufficient provision of training and no any contractor take query about the labors whether they are trained, experienced or knows the work properly. According to Williams and OwusuAcheampong [8, 9], Strategy of Human resource should be adopted effectively in labour intensive industry to stop turn over.

As per the response collected from different contractors and their project managers the working performance are satisfactory. The contractors assume that if $100 \mathrm{~kg} /$ day $/ \mathrm{man}$ as satisfactory performance regarding to rebar works. Similarly if labors perform $0.7 \mathrm{~m}^{3} /$ day/man concreting work and $4.5 \mathrm{~m}^{2} /$ day/man Scaffolding/ formwork, contractors assume it satisfactory in their construction activities.

There is no any performance evaluation test adopted in Nepal so far. However, with respect to time and experience their incentive and wages are increased. It is observed that labors enroll as unskilled ones but leave the organization with enhancement in their skill through experience and on the job trainings. But due to lack of adaptation of any specified skill testing techniques, the level of existing labor force are not being measured. This creates difficulty in knowing the status of labor, what type of training do they require or what facilities to be provided to them for enhancement of their work efficiency. 
For the overall development of labor at work site, they require additional facilities such as health and safety related activities through clients and contractors. To know the perception of clients and contractors this study used 5 rank likert scale questionnaire. These perception of clients and contractors on health and safety facilities were measured using 5 rank likert scale questionnaire, on taking the weighted average of the responses the result were presented as in following table.

Table-4: Comparison of client's and contractor's perception on health and safety facilities

\begin{tabular}{|l|l|l|l|}
\hline S. No. & Rank & Client's responses & Contractor's responses \\
\hline & Health Facilities & & \\
\hline 1 & Safe drinking water & 4.78 & 5.00 \\
\hline 2 & Washing Facilities & 4.22 & 3.67 \\
\hline 3 & Suitable accommodation to rest & 4.22 & 4.67 \\
\hline 4 & Catering service & 3.56 & 3.00 \\
\hline 5 & Provision of toilet & 4.67 & 5.00 \\
\hline 6 & First-aid /Medical Facilities & 5.00 & 5.00 \\
\hline & Safety Facilities & & \\
\hline 1 & Safety signs & 5.00 & 3.67 \\
\hline 2 & Safety Helmet and hard hats & 5.00 & 4.67 \\
\hline 3 & Safety glasses, goggles, and face shields & 4.89 & 4.00 \\
\hline 4 & Safety boots & 5.00 & 5.00 \\
\hline 5 & Rain gear & 3.89 & 3.00 \\
\hline 6 & Hearing protection & 4.44 & 3.00 \\
\hline 7 & Knee pads & 4.56 & 3.00 \\
\hline 8 & Gloves & 4.78 & 4.00 \\
\hline 9 & Flashlights & 5.00 & 4.00 \\
\hline 10 & Ladder Scaffold platforms & 4.89 & 4.67 \\
\hline
\end{tabular}

Table 4 indicated that both the clients as well as contractors agree on each health and safety related factors. Both the parties agree the importance of providing above mentioned facilities related to health and safety but they do not provide the specification up to which standard it should be provided in construction sites. This is clearly shown by data of above tables where contactors agree with the facilities provided by them whereas same facilities are considered neutrally provided to the labors by the contractors in view of clients.

\section{Challenges and Measures for Social Security of Labors}

Social security may also refer to the action programs of government intended to promote the welfare of the population through assistance measures guaranteeing access to sufficient resources for food and shelter and to promote health and well-being for the population at large and potentially vulnerable segments such as children, the elderly, the sick and the unemployed.

The Labor Act requires the retirement fund such as (a) gratuity, and (b) provident fund to be deposited in the Social Security Fund.

\section{Challenges for social security of labors Job guarantee}

On interview with the contractors, project managers of the contractors, agents and questionnaire survey with labors, this study comes across the fact that the contractors themselves are on doubt whether they are going to receive more number of projects or not, even existing projects are difficult for them to handle efficiently. Due to this the agents of the labor suppliers also face difficulty which ultimately impacts the labors to secure their job. Thus, for the employers it is difficult and challenging for them to maintain their own workforce and provide job guarantee to the agents and labors.

\section{Remuneration}

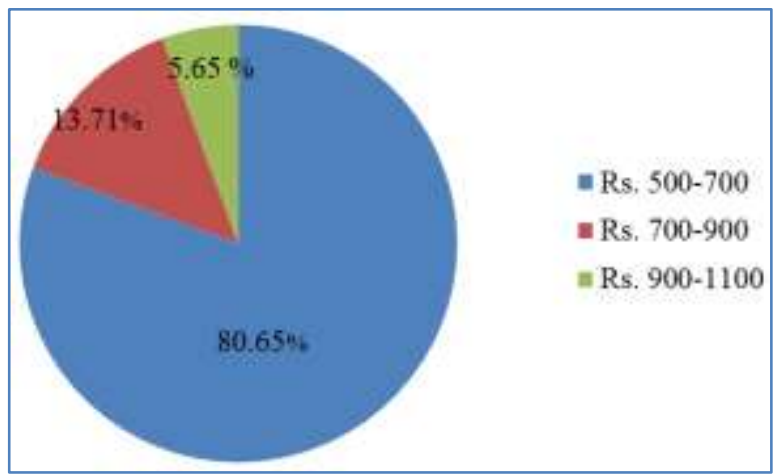

Fig-4: Average daily wages of labors

Figure 4 shows the status of average daily income of labors. The data reveals that majority $(80.65$ percent) of the labors earn daily income ranging Rs.500-700. Similarly, only 13.71 percent of the labors earn daily income of Rs 700-900 and very few i.e. 5.65 percent of the labors earn daily income ranging Rs 9001100. This wages do not include any type of weekly/occasional/ situational leave. All the leaves are unpaid once. Thus the average monthly income of 
labors is insufficient for them to fulfill their basic requirements such as food, accommodation, clothing, etc.

\section{- Health and safety facilities}

The status of health checkup done by the labors. The data indicates that majority of the labors (80.65 percent) have not done any type of health checkup and only few i.e. 19.35 percent of labors are found to have their health status checked.

Among those labors that have gone for health checkup, majority of them do so because it is a mandatory procedure for aboard job employment. There are no health checkup facilities provided by the agents, client and the contractors at the construction sites. Similarly, the level of knowledge about safety awareness in labors. Although the data reveals that majority ( 97.58 percent) of the labors are aware of such safety and only few of them i.e. 2.42 percent of the labors are unaware of it, neither labors themselves utilize such awareness nor contractors provide required level of safety gears to them. The safety gears provided by the employers are insufficient to reduce the accidental hazards.

\section{- Provisions for leave (paid leave)}

During this study it was found that, the labors usually do not get any type of leave. In case they get leave it is provided to them in unpaid form.

\section{- Compensation for undesired leave}

Labors desire to get additional compensation for any type of undesired leaves taken by them such as:

- accidental leaves occurred during working hours with in the work premises

- leaves due to unavailability of equipments, materials, etc.

- leaves due to local disturbances like strikes, riots, disputes, etc.

- leaves due to natural disturbances like heavy rainfall, flood, etc.

\section{Measures for the Social Security of Labors}

According to ILO, Nepal has a population of 26.5 million which is growing fast, resulting in a young country with 63.7 per cent of the total population below the age of 30 . The unemployment rate for youth aged 15-29 is 19.2 per cent compared to 2.7 per cent for the whole population. Over 400,000 young people are estimated to enter the labor force every year. These figures indicate the quantitative dimension of the employment challenge in Nepal. To compensate the unemployment, government can prepare a policy for unemployment incentive to the labors under specified conditions for certain period of time and policy for creation of job opportunity.

While undergoing this study, majority of the labor force were found below poverty line. So the requirement of regular payment in fixed interval is most desired and needed by them, but this cannot be seen in real workplace. If the labors could receive their payments on time, they would be able to manage their daily livelihood smoothly and allocate their expenses accordingly. Thus, the contractors shall try to make their payments on time. Regarding to incentive payments it is seen that only overtime incentives are being provided but labors desires to get something above and beyond their actual pay. Thus, the contractors/ agents shall include some additional benefit to the labors in terms of incentive to them such as encouragement incentive, profit bonus, etc.

While interviewing the clients they claim that they provide labor insurance through BOQ and contractors also confirm that they provide labor insurance facility which was not found in real practice. There is no practice of maintaining any record regarding the major or minor accidents/injury/sickness on the workplace. As such type of incidents occur in regular basis at any workplace thus, record keeping is important. Hence, benefits for accidents/injuries/ sickness, etc. shall be provided by the contractors and monitored by the clients. By doing this, there will be better utilization of the fund allocated for it and also the labor satisfaction will increase through such compensation.

\section{CONCLUSIONS}

Based on this study following conclusions are made: In construction industry for continuous execution of work, availability of labor is very essential. The result indicates the fluctuation in availability of labor, mainly in the month of January, June, July, September and October due to festivals and agricultural purposes. The origin of the labor differ the nature of the work they perform. This study concludes that not all the labor force belongs to same geographical zone nor performs the work of similar nature. Majority of the labors are available in Nepal except for piling works. The data indicates that the most available labor are for general works but not for new emerging type of works such as retrofitting, piling, electromechanical work. The result indicates that there is no any performance test followed by the contractors or agents however they are satisfied if their schedule work is completed within the time frame. Majority of the workers were found to have a work experience of 5-10 years, very few numbers of labors were found to have more years of work experience because of the low job guarantee, trend of migrating abroad for better employment. Only 6\% (8 out of 124) of the labors were trained and remaining received on the job training, which is not considered as any tested skilled training.

Construction companies do not have their own work force as they depend mostly on the agents or labor suppliers. Only $20 \%$ (2 out of 10) agents were found registered, which indicates that the actual data related to 
labor is insufficient. Both the clients and contractors were agreed for providing health and safety facilities to workers though the facilities were not satisfactory at site. The factors increasing the productivity of the labor are good management of the workers, amount of remuneration, number of training courses, facilities of workplace (availability material \& equipment) and complexity of project, management experience and absenteeism from the work site are factors responsible for reduction in productivity of labor.

Furthermore, the major challenges for labor management were job guarantee, remuneration paid to them, health and safety facility provided to them, provision of leave and compensation for undesirable leave. This study also indicates that the bid documents include provision of insurance, health and safety facilities, camp facilities and toilet, traffic management. Because of the rule of providing the projects to one who bids the lowest rate, the bidders compromise in above mentioned facilities which directly hamper the labor management at construction site.

\section{RECOMMENDATIONS}

To reduce effect of the unavailability of labors, the clients and the contractors should consider it while preparing the construction schedule. As labors availability as per their nature of skill dependents upon the source of their origin and their ancestor's experience, the contractors and the agents can conduct a pilot study on availability of source of labor to fulfill their requirements. As construction industry is adopting new technology and methodology of working, it requires certified training for special type of work. Along with it the government as well as the construction companies can make the labors multitasking through trainings so that they can increase the construction output. Through the creation of better job opportunity and providing satisfactory wages the trend of migration of labors and the brain drain can be reduced. Regular training, tool box talk, quality culture should be provided to the labors.

Registration of the agent or labor supplier should be enforced and data base of the labor should be maintained. It is also suggested to maintain the labor card at each work place, so that individual detail of each labor can be recorded. For the enhancement in the level of health and safety related facilities, there should be regular monitoring of the facilities and technical as well as social audit is required. To reduce the challenges related tolabor management, there should be job guarantee to the labors. In the case of remuneration, hazard mapping should be done and wages should be fixed as accordingly. Government should make provisions for appropriate compliance of labor act along with sufficient monitoring of it by the concerned government authority to enforce proper and suitable personal protective equipment (PPE). The concerned government authorities are suggested to raise social security fund on the basis of labor card if any provided to them. It is also suggested that along with low bidding rule to provide the project, priority should also be given to technical specification and working methodology. Working methodology, health and safety facilities, site infra-structure should be incorporated through submittals of contract.

\section{ACKNOWLEDGEMENTS}

I would like to express my deepest thanks to all the helping hands without which this work would not have been completed. This research is dedicated to all the people affected from COVID 19 and hope the world is going to come over this problem.

\section{REFERENCES}

1. Mishra, A. K., \& Shrestha, M. (2017). Health and safety status of casual workers in road improvement project Kathmandu Valley, Nepal. International Journal of Engineering Technology Science and Research (IJETSR), 4(9), 1187-1199.

2. Mishra, A. K. (2018). Assessment of Human Resource Capacity of Construction Companies in Nepal. J Adv Res Jour Mass Comm, 5(4), 14-25.

3. Maskey, A., Mishra, A.K. (2018). Labor productivity assessment of armed police force Nepal building construction projects. International Journal of Current Research, 10(11) https://doi.org/10.24321/2454.3268.201804.

4. Kazaz, A., Manisali, E., \& Ulubeyli, S. (2008). Effect of basic motivational factors on construction workforce productivity in Turkey. Journal of civil engineering and management, 14(2), 95-106.

5. Jarkas, A. M., \& Bitar, C. G. (2012). Factors affecting construction labor productivity in Kuwait. Journal of construction engineering and management, 138(7), 811-820.

6. Krejice and Morgan Table. (1970). Available from http://in-troh-

spective.blogspot.com/2017/10/krejcie-andmorgan-sampling-method.html

7. Adnan, E., Sherif, M., Ziad, A. M., \& Peter, E.M. (2007). Factors Affecting Labour Productivity In Building Projects In The Gaza Strip [Journal] // Journal of Civil Engineering And Management. [s.1.]: Journal of Civil Engineering And Management, 4(13), 245-254.

8. Williams, A. A., \& Owusu-Acheampong, E. (2016). Human resource management practices and their effect on employee turnover in the hotel industry in Cape Coast, Ghana. Global Journal of Human Resource Management, 4(4), 35-45.

9. ILO. (2005). Decent Civil Works in Nepal:From Research to Action Planning, Kathmandu: ILO. 